\title{
Effect of Harvesting Stage and Drying Method on Seed Quality of Okra [Abelmoschus esculentus(L) Moench]
}

\author{
Nitish Kumar ${ }^{1}$, Mukesh Kumar ${ }^{1 *}$, Arun Kumar ${ }^{1}$, \\ Prabhash Kumar Singh ${ }^{1}$ and Vijay Kumar Singh ${ }^{2}$
}

\author{
${ }^{1}$ Department of Seed Science and Technology, ${ }^{2}$ Department of Horticulture (Vegetable \\ Science), Bihar Agricultural University, Sabour, Bhagalpur, (Bihar), India
}

*Corresponding author

\section{A B S T R A C T}

\begin{tabular}{|l|}
\hline K e y w o r d s \\
Okra, Harvesting \\
Stage, Drying \\
Method, Seed \\
Vigour
\end{tabular}

\begin{abstract}
The present investigation was conducted at the Research Farm, Bihar Agricultural College, Sabour, Bhagalpur (Bihar) during kharif season 2019 with objective to identify the influence of harvesting stage and drying method quality seed productions of okra. The okra cv Super Green was sown in Kharif 2019 and fruits/capsules was divided into two lots were harvested at four different maturity stages i.e. 25, 30, 35 and 40 days after anthesis (DAA) was subjected to sun drying and shade drying respectively and then seeds were extracted from the capsule for measurement of seed quality parameters. It was found that okra fruit harvested at 40 days after anthesis having significantly higher standard germination and vigour. The drying of okra seed under shade was found significantly better in all laboratory parameters than sun drying. In other way we can say that slow drying of okra seed recommended subject to optimum stage of harvest for good quality seed production.
\end{abstract}

\section{Introduction}

Okra [Abelmoschus esculentus (L) Moench] is an important vegetable crop predominantly grown in tropics and subtropics, belongs to family Malvaceae. It is a warm season vegetable that produces long, thin, edible pods commonly known as ladies 'fingers. The crop is cultivated for its young tender fruits, used in curry and soups after cooking. It is a good source of vitamins A and B, protein, calcium, phosphorus, fibre and minerals (Tindall, 1983). The low productivity in okra is attributed by poor seed replacement ratio due to limited availability of quality seed and its supply. Use of quality seeds is a prerequisite for successful vegetable production. Quality of okra seed is affected by many factors such as stage of harvesting, drying methods, seed moisture content (Demir, 2001). Harvesting stage is one of the factors affecting both seed yield and quality. Immature and over mature fruits for seed purpose will result reduction in yield and its quality. Fruits harvested at physiological maturity produce high quality seed as compared to fruits harvested at earlier or later stage of maturity. seeds attain maximum 
quality in terms of germinability at the end of the seed filling period and thereafter viability and vigour declines. (Harrington, 1960). At the time of harvesting, okra capsule having high moisture content which is unsafe for processing and storage and it requires proper drying. Drying of okra capsule to reduce the water content and improve the keeping quality. It reduces the seed respiration by removal of excess moisture and to prevent the qualitative deterioration of seed. Stage and method of drying i.e. slow and fast, influences the seed vigour and germination as reported by many researchers. Seed may be injured by drying too rapidly or over drying and cause poor seed vigour and viability. Method of drying also influences the formation of hard seed coat which cause hardseededness (Luis Felipe et al., 2010). The seed crop requires the right stage of maturity followed by proper drying to ensure high germinability after harvest and storage (Demir, 2005). This is because seed longevity is known to be influenced by the initial seed quality, which is affected by the production procedure. This study was therefore conducted to evaluate the impact of harvesting stage and drying methods seed quality of okra.

\section{Materials and Methods}

Okra cultivar Super green, was taken for present investigation which is one of the popular private sector variety. This variety was sown in Kharif 2019 and fruits were harvested at four different maturity stages i.e. $25,30,35$ and 40 days after anthesis (DAA).

These harvested fruits/capsules were divided into two lots. The fruits/capsule of first and second lot harvested at 25, 30, 35 and 40 days after anthesis (DAA) was first subjected to sun drying and shade drying respectively for 7 days and then seeds were extracted manually from the capsule and kept separately. The extracted seeds were packed in separate muslin cloth bag and kept for natural drying at ambient conditions and then seed of each sub-lot were used for laboratory analysis. The parameters measured were standard germination, seedling length, seedling dry weight, vigour index I and II, and Electrical conductivity.

\section{Treatment details}

$\mathrm{H}_{1} \mathrm{D}_{1}$ (Capsule harvesting at 25 Days after Anthesis followed by Sun Drying)

$\mathrm{H}_{1} \mathrm{D}_{2}$ (Capsule harvesting at 25 Days after Anthesis followed by Shade Drying)

$\mathrm{H}_{2} \mathrm{D}_{1}$ (Capsule harvesting at 30 Days after Anthesis followed by Sun Drying)

$\mathrm{H}_{2} \mathrm{D}_{2}$ (Capsule harvesting at 30 Days after Anthesis followed by Shade Drying)

$\mathrm{H}_{3} \mathrm{D}_{1}$ (Capsule harvesting at 35 Days after Anthesis followed by Sun Drying)

$\mathrm{H}_{3} \mathrm{D}_{2}$ (Capsule harvesting at 35 Days after Anthesis followed by Shade Drying)

$\mathrm{H}_{4} \mathrm{D}_{1}$ (Capsule harvesting at 40 Days after Anthesis followed by Sun Drying)

$\mathrm{H}_{4} \mathrm{D}_{2}$ (Capsule harvesting at 40 Days after Anthesis followed by Shade Drying)

\section{Observation}

\section{Number of Seeds per Capsule}

Seeds extracted from ten capsules of each harvesting stage were collected and counted separately. The mean value was noted as number of seeds capsules per plant.

\section{0 seed weight $(g)$}

A random sample from pure seed fraction was used for estimating 100 seed weight. Eight replicate of 100 seed were weighted for each seeds of each harvesting stage. The mean value was expressed in grams.

\section{Seed moisture content (\%)}


Moisture content of seed was determined by the low constant temperature oven method i.e. $103^{\circ} \mathrm{C}$ for 17 hour according to International Seed Testing Association (2015). Okra seed were coarse grinded in two replicates of $5 \mathrm{~g}$ seeds and put in aluminiummade analytical container of $9 \mathrm{~mm}$ in diameter.

After one hour of drying at $103^{\circ} \mathrm{C}$ for 17 hour, seeds were immediately removed and kept in desiccators for cooling. Seeds were reweighed and the weight difference was used to compute the seed moisture content using the formula:

$$
\operatorname{SMC}(\%)=\frac{\mathrm{M} 2-\mathrm{M} 3^{\mathrm{M} 2-\mathrm{M} 1}}{2100}
$$

Where, $\mathrm{M}_{1}=$ Weight of the container and its cover in grams.

$\mathrm{M}_{2}=$ Weight of the container, its cover and its contents before drying in grams.

$M_{3}=$ Weight of the container, its cover and its contents after drying in grams.

\section{Standard germination (\%)}

Seeds from pure seed fraction were used for estimation of standard germination (\%). The germination test was conducted by between paper (BP) methods. Eight replicates of 50 seeds each were tested by following ISTA method (2015).In this method, seed sample was placed between two layer of wet germination paper which was then rolled and wrapped in a sheet of wax paper so as to keep the surface evaporation at minimum. Further sample was kept in germinator in upright position at $25 \pm 1{ }^{\circ} \mathrm{C}$ temperature and 95 percent relative humidity for eight days. At the end, seeds were evaluated calculate standard germination $(\%)$.

Germination (\%) Number of seeds tested

\section{Seedling length $(\mathrm{cm})$}

Ten normal seedlings were taken at random from each replication. The total seedling length (shoot and root length) selected seedlings was measured in centimeters with the help of scale in each replication and average of them was calculated.

\section{Seedling dry weight (gram)}

Ten normal seedling per replication which were selected at random for observing total seedling length were dried in a hot air oven at $80 \pm 1^{\circ} \mathrm{C}$ for 24 hours and then cooled in desiccators. Seedling dry weight was expressed as $\mathrm{g} / 10$ seedling.

\section{Vigour index}

The vigour indices were computed adopting the method of abdul-Baki and Anderson (1973) by using following formula.

Seed vigour index $\mathrm{I}=$ Germination percentage $\times$ Total seedling length $(\mathrm{cm})$

Seed vigour index II $=$ Germination percentage $\times$ seedling dry weight $($ gram)

\section{Electrical conductivity}

Measurement of the electrical conductivity of leachate provides an assessment of the extent of electrolyte leakage from seed tissues. Conductivity measurement of the soaked seeds in which sample of okra seeds has been steeped gives an estimate of seed vigour. The samples that have high electrolyte leakage (high electrical conductivity) are considered as having low vigour, while those with low leakage (low conductivity) are considered as high vigour. 


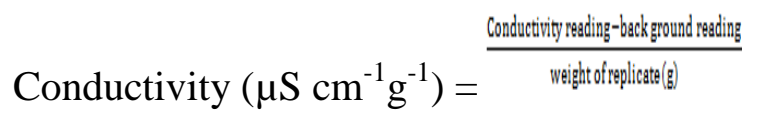

\section{Results and Discussion}

Seed development and maturation are complex sequences of events occurring over a period of time. Accumulation of reserve food material, cessation of embryo growth, tegument differentiation, tolerance to desiccation development, and dormancy induction etc are the events associated with seed maturations. Levels of moisture content in seed also vary during the process of maturation. Initially in developing there is high moisture content, and with progress of maturity, it comes down. Generally, the moisture content at physiological maturity varies from 17.0 percent to 22.0 percent in case of most orthodox seed (Table 1-7).

Based on the results of our present studies, we found that when okra capsule was harvested at 25 days after anthesis (DAA), the seed moisture content was highest $(54.0 \%)$ and further, it comes down with progress of maturity, and was found minimum at capsule harvested at 40 days after anthesis (DAA) (Table 1). Similar, results of decline in seed moisture content at later period of harvest was also reported by Demir and Ermis (2005). The reduction with advancement of maturity might be due to the events associated with development of seeds such as accumulation of dry matter, desiccation development, cessation of mobilisation etc.

Germination percentage and seed vigour are an important parameters for determining the physiological maturity of seeds (Singh and Sindhu, 1985). We have analysed the extracted and desiccant dried seeds from four stages of maturity i.e. 25, 30, 35, and 40 days after anthesis (DAA) and found that standard germination and seed vigour index $\mathrm{i}$ and II found maximum in capsules of 40 DAA. This show that among all these four stage of maturity, seed quality of harvested seed from capsules of 40 DAA maturity stage was found more vigorous. However, desiccation drying may harmful for drying extracted seed having high moisture.

The superior longevity of seeds harvested at 40 DAA over those at 35 DAA suggests that though seeds might have attained physiological maturity at 35 DAA, occasioning high germination percentages, more seed filling was still needed for maximum vigour which must have occurred at 40 DAA. Maximum germination percentage was found in seeds from capsule harvested at 40 days after anthesis (DAA) in okra cv Super Green (91 \%) (Table 2). Devadas et al., (1998) reported that the developing seeds attained germinable maturity at 21 days after anthesis and highest germination was recorded at 30 to 36 days after anthesis. This was also supported with findings of Berchie et al., (2004), Ibrahim and Oladiran (2011). Okra cv Super Green showed increasing seed vigour index with the seed maturity with highest at 40 days after flowering (2097).

These results are in conformity with those of Sajjan and Jamadar (2003), who observed that harvesting of okra fruits at 40 days after flowering was statistically significant over all the harvesting stages in terms of seed vigour index (Table 5 and 6).

The electrical conductivity of seed leachate of desiccant dried seed was recorded with the numerically maximum value was recorded in 25 DAA (0.325dsm-1) and lowest at 40 DAA (0.205 dsm-1) (Table 7). These results are similarly to the findings of Sankar and Mani (2015). The higher seed leachate conductivity could also be an indicator of reduced seedcoat membrane integrity this results from increased plasma membrane permeability 
which induces higher solute leakage, and thereby affects seed germination. Electrical conductivity of seed leachate decreased with increase in seed size or seed maturity.

The seed harvested at physiological maturity or harvest maturity is generally not safe for storage and processing due to high moisture content. So, it is subjected for safe method of drying to retain the vigour and viability. There is several method of drying okra fruit/capsule to reduce the water content and improve the keeping quality of seed. Drying reduce the seed respiration by removal of excess moisture and to prevent the qualitative deterioration of seed. The seeds of okra can be dried with pod without pod, slow dry or fast dry and natural or artificial drying etc. Many studies were conducted in several crops to find out effect of during method on standard germination and vigour of seed.

Table.1 Effect on number of seed/capsule, 100 seed weight and seed moisture content of fruit harvested at different stages

\begin{tabular}{|l|c|c|c|c|}
\hline $\begin{array}{c}\text { Stage of Harvesting } \\
(\mathbf{H})\end{array}$ & $\begin{array}{c}\text { No. of Seed Per } \\
\text { Capsule }\end{array}$ & $\begin{array}{c}\text { Fresh 100 } \\
\text { Seed Weight } \\
(\mathbf{g})\end{array}$ & $\begin{array}{c}\text { Seed Moisture } \\
\text { content(\%) at } \\
\text { harvesting }\end{array}$ & $\begin{array}{c}\text { Dried 100 } \\
\text { seed Weight } \\
(\mathbf{g})\end{array}$ \\
\hline $\mathbf{H}_{\mathbf{1}}$ (25 DAA) & 66.000 & 6.923 & 54.67 & 4.813 \\
\hline $\mathbf{H}_{\mathbf{2}}$ (30 DAA) & 66.667 & 6.821 & 48.33 & 4.950 \\
\hline $\mathbf{H}_{3}$ (35 DAA) & 65.000 & 6.002 & 25.16 & 5.233 \\
\hline H $_{\mathbf{4}}$ (40 DAA) & 66.000 & 5.329 & 18.67 & 5.210 \\
\hline C.D. (P=0.05) & $\mathbf{N S}$ & $\mathbf{0 . 2 7 8}$ & $\mathbf{4 . 5 4}$ & $\mathbf{0 . 1 3}$ \\
\hline
\end{tabular}

H: Stage of Harvesting; $\mathrm{H}_{1}$ : Capsule Harvesting at 25 Days after Anthesis; $\mathrm{H}_{2}$ : Capsule Harvesting at 30 Days after Anthesis; $\mathrm{H}_{3}$ : Capsule Harvesting at 35 Days after Anthesis; $\mathrm{H}_{4}$ : Capsule Harvesting at 40 Days after Anthesis

Table.2 Effect of drying method on standard germination of okra seed harvested at different maturity stage

\begin{tabular}{|c|c|c|c|}
\hline \multirow{2}{*}{$\begin{array}{c}\text { Stage of Harvesting } \\
(\mathbf{H})\end{array}$} & \multicolumn{3}{|c|}{ Standard Germination (\%) } \\
\hline & Sun Drying $\left(D_{1}\right)$ & Shade Drying $\left(\mathrm{D}_{2}\right)$ & Mean $(\mathbf{H})$ \\
\hline $\mathrm{H}_{1}(25$ DAA $)$ & 56.00 & 76.00 & 66.00 \\
\hline $\mathrm{H}_{2}$ (30 DAA) & 58.33 & 80.00 & 69.17 \\
\hline $\mathrm{H}_{3}$ (35 DAA) & 72.67 & 89.33 & 81.00 \\
\hline $\mathrm{H}_{4}(40$ DAA $)$ & 76.33 & 91.00 & 83.67 \\
\hline Mean (D) & 65.83 & 84.08 & \\
\hline \multicolumn{4}{|l|}{ C.D. $(P=0.05)$} \\
\hline $\mathbf{H}$ & \multicolumn{2}{|c|}{3.56} & \\
\hline D & \multicolumn{2}{|c|}{2.52} & \\
\hline H x D & \multicolumn{2}{|c|}{ NS } & \\
\hline
\end{tabular}

H: Stage of Harvesting; D: Drying Method; $\mathrm{H}_{1}$ : Capsule Harvesting at 25 Days after Anthesis; $\mathrm{H}_{2}$ : Capsule Harvesting at 30 Days after Anthesis; $\mathrm{H}_{3}$ : Capsule Harvesting at 35 Days after Anthesis; $\mathrm{H}_{4}$ : Capsule Harvesting at 40 Days after Anthesis; $\mathrm{D}_{1}$ : Capsule dried in Sun; $\mathrm{D}_{2}$ : capsule dried in shade 
Table.3 Effect of drying method on seedling length of okra seed harvested at different maturity stage

\begin{tabular}{|c|c|c|c|}
\hline \multirow{2}{*}{$\begin{array}{c}\text { Stage of Harvesting } \\
(\mathbf{H})\end{array}$} & \multicolumn{3}{|c|}{ Seedling Length (cm) } \\
\hline & Sun Drying $\left(D_{1}\right)$ & Shade Drying $\left(\mathrm{D}_{2}\right)$ & Mean $(\mathrm{H})$ \\
\hline $\mathrm{H}_{1}(25$ DAA $)$ & 28.85 & 29.87 & 29.36 \\
\hline $\mathrm{H}_{2}(30 \mathrm{DAA})$ & 30.00 & 31.31 & 30.66 \\
\hline $\mathrm{H}_{3}(35 \mathrm{DAA})$ & 31.24 & 30.65 & 30.94 \\
\hline $\mathrm{H}_{4}(40$ DAA $)$ & 31.80 & 32.17 & 31.98 \\
\hline Mean (D) & 30.47 & 31.00 & \\
\hline \multicolumn{4}{|l|}{ C.D. $(P=0.05)$} \\
\hline H & \multicolumn{2}{|c|}{1.25} & \\
\hline D & \multicolumn{2}{|c|}{ NS } & \\
\hline H x D & \multicolumn{2}{|c|}{ NS } & \\
\hline
\end{tabular}

H: Stage of Harvesting; D: Drying Method; $\mathrm{H}_{1}$ : Capsule Harvesting at 25 Days after Anthesis; $\mathrm{H}_{2}$ : Capsule Harvesting at 30 Days after Anthesis; $\mathrm{H}_{3}$ : Capsule Harvesting at 35 Days after Anthesis; $\mathrm{H}_{4}$ : Capsule Harvesting at 40 Days after Anthesis; $\mathrm{D}_{1}$ : Capsule dried in Sun; $\mathrm{D}_{2}$ : capsule dried in shade

Table.4 Effect of drying method on Seedling dry weight of okra seed harvested at different maturity stage

\begin{tabular}{|c|c|c|c|}
\hline \multirow{2}{*}{$\begin{array}{c}\text { Stage of Harvesting } \\
(\mathbf{H})\end{array}$} & \multicolumn{3}{|c|}{ Seedling Dry weight (mg) } \\
\hline & Sun Drying $\left(D_{1}\right)$ & Shade Drying $\left(\mathrm{D}_{2}\right)$ & Mean (H) \\
\hline $\mathrm{H}_{1}(25$ DAA $)$ & 242 & 257 & 250 \\
\hline $\mathrm{H}_{2}$ (30 DAA) & 261 & 267 & 264 \\
\hline $\mathrm{H}_{3}$ (35 DAA) & 287 & 291 & 289 \\
\hline $\mathrm{H}_{4}(40$ DAA $)$ & 292 & 294 & 293 \\
\hline Mean (D) & 271 & 277 & \\
\hline \multicolumn{4}{|l|}{ C.D. $(P=0.05)$} \\
\hline H & \multicolumn{2}{|c|}{24} & \\
\hline D & \multicolumn{2}{|c|}{ NS } & \\
\hline H x D & \multicolumn{2}{|c|}{ NS } & \\
\hline
\end{tabular}

H: Stage of Harvesting; D: Drying Method; $\mathrm{H}_{1}$ : Capsule Harvesting at 25 Days after Anthesis; $\mathrm{H}_{2}$ : Capsule Harvesting at 30 Days after Anthesis; $\mathrm{H}_{3}$ : Capsule Harvesting at 35 Days after Anthesis; $\mathrm{H}_{4}$ : Capsule Harvesting at 40 Days after Anthesis; $\mathrm{D}_{1}$ : Capsule dried in Sun; $\mathrm{D}_{2}$ : capsule dried in shade

Table.5 Effect of drying method on Seed Vigour Index-I of okra seed harvested at different maturity stage

\begin{tabular}{|c|c|c|c|}
\hline \multirow{2}{*}{$\begin{array}{c}\text { Stage of Harvesting } \\
(\mathbf{H})\end{array}$} & \multicolumn{3}{|c|}{ Seed Vigour Index-I } \\
\hline & Sun Drying $\left(D_{1}\right)$ & Shade Drying $\left(\mathrm{D}_{2}\right)$ & Mean (H) \\
\hline $\mathbf{H}_{1}(25$ DAA $)$ & 1,616 & 2,273 & 1,945 \\
\hline $\mathrm{H}_{2}(30$ DAA $)$ & 1,750 & 2,505 & 2,128 \\
\hline $\mathrm{H}_{3}$ (35 DAA) & 2,270 & 2,738 & 2,504 \\
\hline $\mathrm{H}_{4}(40$ DAA $)$ & 2,428 & 2,927 & 2,678 \\
\hline Mean (D) & 2,016 & 2,611 & \\
\hline \multicolumn{4}{|l|}{ C.D. $(P=0.05)$} \\
\hline $\mathbf{H}$ & \multicolumn{2}{|c|}{155} & \\
\hline D & \multicolumn{2}{|c|}{110} & \\
\hline$H \times D$ & \multicolumn{2}{|c|}{ NS } & \\
\hline
\end{tabular}

H: Stage of Harvesting; D: Drying Method; $\mathrm{H}_{1}$ : Capsule Harvesting at 25 Days after Anthesis; $\mathrm{H}_{2}$ : Capsule Harvesting at 30 Days after Anthesis; $\mathrm{H}_{3}$ : Capsule Harvesting at 35 Days after Anthesis; $\mathrm{H}_{4}$ : Capsule Harvesting at 40 Days after Anthesis; $\mathrm{D}_{1}$ : Capsule dried in Sun; $\mathrm{D}_{2}$ : capsule dried in shade 
Table.6 Effect of drying method on Seed Vigour Index-II of okra seed harvested at different maturity stage

\begin{tabular}{|c|c|c|c|}
\hline \multirow{2}{*}{$\begin{array}{c}\text { Stage of Harvesting } \\
(\mathbf{H})\end{array}$} & \multicolumn{3}{|c|}{ Seed Vigour Index-II } \\
\hline & Sun Drying $\left(D_{1}\right)$ & Shade Drying $\left(D_{2}\right)$ & Mean $(\mathrm{H})$ \\
\hline $\mathrm{H}_{1}(25 \mathrm{DAA})$ & 13,593 & 19,586 & 16,589 \\
\hline $\mathrm{H}_{2}$ (30 DAA) & 15,234 & 21,275 & 18,254 \\
\hline $\mathrm{H}_{3}$ (35 DAA) & 20,880 & 26,027 & 23,454 \\
\hline $\mathrm{H}_{4}(40$ DAA $)$ & 22,325 & 26,730 & 24,528 \\
\hline Mean $(D)$ & 18,008 & 23,405 & \\
\hline \multicolumn{4}{|l|}{ C.D. $(P=0.05)$} \\
\hline $\mathbf{H}$ & \multicolumn{2}{|c|}{2068} & \\
\hline D & \multicolumn{2}{|c|}{1462} & \\
\hline H $\times$ D & \multicolumn{2}{|c|}{ NS } & \\
\hline
\end{tabular}

H: Stage of Harvesting; D: Drying Method; $\mathrm{H}_{1}$ : Capsule Harvesting at 25 Days after Anthesis; $\mathrm{H}_{2}$ : Capsule Harvesting at 30 Days after Anthesis; $\mathrm{H}_{3}$ : Capsule Harvesting at 35 Days after Anthesis; $\mathrm{H}_{4}$ : Capsule Harvesting at 40 Days after Anthesis; $\mathrm{D}_{1}$ : Capsule dried in Sun; $\mathrm{D}_{2}$ : capsule dried in shade

Table.7 Effect of drying method on Electrical Conductivity of okra seed harvested at different maturity stage

\begin{tabular}{|c|c|c|c|}
\hline \multirow{2}{*}{$\begin{array}{c}\text { Stage of Harvesting } \\
(\mathbf{H})\end{array}$} & \multicolumn{3}{|c|}{ Electrical Conductivity $\left(\mu S \mathrm{~cm}^{-1} \mathrm{~g}^{-1}\right)$} \\
\hline & Sun Drying $\left(D_{1}\right)$ & Shade Drying $\left(\mathrm{D}_{2}\right)$ & Mean $(\mathbf{H})$ \\
\hline $\mathrm{H}_{1}(25$ DAA $)$ & 0.270 & 0.240 & 0.255 \\
\hline $\mathrm{H}_{2}(30$ DAA $)$ & 0.224 & 0.196 & 0.210 \\
\hline $\mathrm{H}_{3}$ (35 DAA) & 0.188 & 0.172 & 0.180 \\
\hline $\mathrm{H}_{4}(40$ DAA $)$ & 0.181 & 0.164 & 0.173 \\
\hline Mean $(D)$ & 0.216 & 0.193 & \\
\hline \multicolumn{4}{|l|}{ C.D. $(P=0.05)$} \\
\hline $\mathbf{H}$ & \multicolumn{2}{|c|}{0.025} & \\
\hline D & \multicolumn{2}{|c|}{0.018} & \\
\hline H x D & \multicolumn{2}{|c|}{ NS } & \\
\hline
\end{tabular}

H: Stage of Harvesting; D: Drying Method; $\mathrm{H}_{1}$ : Capsule Harvesting at 25 Days after Anthesis; $\mathrm{H}_{2}$ : Capsule Harvesting at 30 Days after Anthesis; $\mathrm{H}_{3}$ : Capsule Harvesting at 35 Days after Anthesis; $\mathrm{H}_{4}$ : Capsule Harvesting at 40 Days after Anthesis; $D_{1}$ : Capsule dried in Sun; $D_{2}$ : capsule dried in shade

In present studies, we had dried the fruits/capsule of second and third lot harvested at 25, 30, 35 and 40 days after anthesis (DAA) under sun and shade respectively for 7 days and then seeds were extracted manually from the capsule and kept separately. The extracted seeds were packed in separate muslin cloth bag and kept for natural drying at ambient conditions and then seed of each sub-lot were used for laboratory analysis.
This investigation shows that the stage of harvest significantly influenced the germination of okra seed even after drying to the recommended moisture content. This implies that the higher the moisture contents at harvest, the lower the percentage germination. This observation is similar to the reports of Owolade et al., (2003) who observed that the higher the moisture content the higher the loss of seed grain to pathogens. Maximum standard germination (72.54\%) was occurred at 40 DAA when seed moisture 
content was lowest $(18.67 \%)$ at the time of harvesting. For seeds like okra, seed moisture content in the seed filling stage is high followed by a drastic loss in water during the maturation drying phase (Bewley and Black, 1994). Low seed moisture content may indicate the degree of maturity, when the essential structures are fully developed, hence the possible increase in percentage germination as observed in this study. This implies that harvesting at 40 DAA could give high seed germination in okra cultivar. Similar results have been reported by Bortey and Dzomeku (2016) who observed that the seed germination percent increased with advancement of maturity. The highest germination percent was recorded by the loss of moisture from the seeds with maturity and Mohammadi et al., (2013) evaluated the harvesting fruits at 40 days after flowering (DAF) resulted in an increase of germination rate, especially Seed germination of seeds harvested at 40 to 50 days after flowering (DAF) was reduced.

The effect of drying methods of okra capsule on standard germination was found significant. The maximum standard germination was reported in shade drying (84.08 percent) and minimum in sun drying (65.83 percent). Similar result was found for vigour index-I and Vigour index-II. Significantly higher vigour index I and II were reported in shade drying (2611 and 23405 ) in comparison to sun drying (2016 and 18008).

In sun drying rate of drying is fast, where in shade slow drying occurs. The reason for low germination and vigour in case of sun drying is evident that drying of high capsule or seeds at high moisture content is detrimental. Shade dried seeds performed significantly better in terms of standard germination and vigour index-I and II irrespective of stage of harvest. These results are in conformity with those of
Sajjan and Jamadar (2003), who observed that harvesting of okra fruits at 40 days after flowering was statistically significant over all the harvesting stages in terms of seed vigour index.

The electrical conductivity of seed leachate of sun dried seed was recorded higher $(0.216 \mu \mathrm{S}$ $\mathrm{cm}-1 \mathrm{~g}-1)$. Higher the value of electrical conductivity indicates the poor quality of seed. This again substantiates the result based on standard germination and vigour index. The finding is very similar to the findings of Sankar and Mani (2015).

The result of present study revealed that effect of stage of harvesting and drying method on seed quality of okra was found significant. It is concluded from the studies that for successful production of okra seed the optimum stage of harvesting is 40 days after anthesis followed by shade drying. In other way we can say that slow drying of okra seed recommended subject to optimum stage of harvest for good quality seed production

\section{Acknowledgement}

Authors are thankful to Bihar Agricultural University, Sabour for all necessary support and funding for research.

\section{References}

Abdul B, Anderson JD (1973) Vigour determination in soyabean by multiple criteria. Crop Science, 13:630-633.

Anonymous (2004) Handbook of ISTA, Zurich, Switzerland.

Anitha P, Sadhankumar PG, Rajan S (2001) Effect of methods of drying on seed quality in okra. No. Research. 2002.

Barnwal AK (2015) Effect of picking stage on fruit and seed development in different okra [Abelmoschus esculentus (L.)Moench] cultivars (Doctoral dissertation, Institute of Agricultural Sciences, Banaras Hindu University). 
Berchie J N, Djietror A and Osei CK (2004) Effect of pod maturation on vegetative growth,fruit yield and seed germination of okra [Abelmoschus esculentus (L.)Moench]. Agricultural and Food Science Journal of Ghana, 3: 227-235.

Bewley J D, Black M (1994) Seed: Physiology of Development and Germination. $2^{\text {nd }}$ ed. Plenum Press, New York, NY,USA. 445 p

Bortey H M, Dzomeku B M (2016). Fruit and seed quality of okra [Abelmoschus esculentus (L.) Moench] as influenced by harvesting stage and drying method. Indian Journal of Agricultural Research, 50(4), 330334.

Demir I (2001) The effects of heat treatment on hardseedness of serially harvested okra seed lot at optimum and low temperatures. Sci Hortic 89:1-7.

Demir I, Ermis S (2005). Effect of harvest maturity and drying method on okra seed quality. Seed Technology, 81-88.

Devadas V S, Rani T G, Kuriakose K J and Nair S $R$ (1998) A note on fruit and seed development in okra [Abelmoschus esculentus (L.) Moench]. Vegetable Science, 25(2):187-189.

Harrington J.F. (1960) Seed storage and longevity. In Seed Biology (Kozlowsli, T.T. Ed.), 3:145-245.

ISTA (2015) International Rules for Seed Testing. International Seed Testing Association, Switzerland

Ibrahim H and Oladiran J A (2011). Effect of fruit age and position on mother-plant on fruit growth and seed quality in okra (Abelmoschus esculentus L. Moench). International Journal of Science and Nature 2(3), 587-592

Kumar V (1998) Effect of stages of harvesting and drying methods on seed yield and quality of paprika chilli \{capsicum annuum
L (Doctoral Dissertation, University of Agricultural Sciences GKVK, Bangalore).

Luis Felipe VP, Antonio A do L, Francisco Antonio P (2010) Germination and hardseedness of seeds in okra elite lines.Hortic Bras 28:232-235.

Mohammadi G, Khah EM, Petropoulos SA, Yarsi G, Vlasakoudis A (2013). Effect of fertilizer and drying methods on seed germination of okra (Abelmoschus esculentus L.) cultivars at different harvesting times. Journal of Agricultural Science, 5(4), 1.

Mohamed M Sh, Ahmed HMI, Ismail AI (2016) Seed Yield and Quality of Okra (Abelmoschus esculentus (L.) Moench) as Influenced by Sowing Dates, Harvest Date and Pod Position, Journal Plant Production, Mansoura Univ., Vol. 7(11): 1137 - 1145.

Sajjan A, Jamadar M M (2003) Influence of harvesting stages and drying methods on seed quality and seed mycoflora in okra seeds in northern dry zone of Karnataka. Karnataka Journal of Agricultural Sciences, 16(3), 461-464

Sajjan AS, Shekargouda M, Biradar BD, Pawar KN, Devaranavadgi SB (2005). Fruit development and seed maturation studies in okra (Abelmoschus esculentus (L) Moench. Indian Journal of Agricultural Research, 39(4), 310-312.

Sankar YS, Mani A (2015) Studies on Seed Quality Parameters of Okra (Abelmoschus esculentus L.) Journal of Agriculture and Technology, 2(2), 79-83.

Tindall, H. D. (1983), Vegetables in the Tropics. Macmillan Press, 1983, xi, 533 p. London

Vahid Q A (2014) Effects of drying methods on seed quality of summer groundnut (Arachis hypogaea L.) during storage (Doctoral Dissertation, Mahatma Phule Krishi Vidyapeeth, Rahuri.).

\section{How to cite this article:}

Nitish Kumar, Mukesh Kumar, Arun Kumar, Prabhash Kumar Singh and Vijay Kumar Singh. 2021. Effect of Harvesting Stage and Drying Method on Seed Quality of Okra [Abelmoschus esculentus (L) Moench]. Int.J.Curr.Microbiol.App.Sci. 10(02): 653-661. doi: https://doi.org/10.20546/ijcmas.2021.1002.079 